\section{A proposal for an evaluation model of pharmaceutical services for malaria}

\author{
Uma proposta de modelo de avaliação \\ para a assistência farmacêutica na malária
}

\author{
1 Escola Nacional de Saúde \\ Pública Sergio Arouca, \\ Fundação Oswaldo Cruz, \\ Rio de Janeiro, Brasil. \\ 2 Health Systems and Services \\ Area, Pan American Health \\ Organization, \\ Washington DC, U.S.A. \\ ${ }^{3}$ Instituto Oswaldo Cruz, \\ Fundação Oswaldo Cruz, \\ Rio de Janeiro, Brasil.
}

Correspondence C. G. S. Osorio-de-Castro Núcleo de Assistência Farmacêutica, Escola Nacional de Saúde Pública Sergio Arouca, Fundação Oswaldo Cruz.

Rua Leopoldo Bulhões 1480, Rio de Janeiro, $R J$ 21041-210, Brasil. claudia.osorio@ensp.fiocruz.br

\begin{abstract}
Malaria is a serious public health problem in over 90 countries worldwide. In Brazil the disease is prevalent in the Amazon and the control rationale is based on early diagnosis and treatment. Quality pharmaceutical services are considered a key element for control. A proposal for evaluating pharmaceutical services for malaria is presented here. A theoretical outline composed of a logical model and an indicator framework is discussed and strives to establish a basis for assessment and judgment of the way in which these services are actually delivered. The aim is to contribute to the understanding of pharmaceutical services for malaria and other endemic diseases, complying with the directives of the Brazilian National Medicines Policy.
\end{abstract}

Pharmaceutical Services; Malaria; National Drug Policy

\author{
Claudia Garcia Serpa Osorio-de-Castro ${ }^{1}$ \\ Gabriela Costa Chaves 1 \\ Adriana Mendoza Ruiz 2 \\ Elaine Silva Miranda 1 \\ Mônica Rodrigues Campos 1 \\ Martha Cecília Suárez-Mútis 3 \\ Letícia Figueira Freitas 1
}

\section{Introduction}

Malaria is a disease limited to tropical and subtropical areas and a serious public health problem in over 90 countries. Some 515 million cases occur annually, causing 1.5 to 2.7 million deaths worldwide, mainly among children under five years of age and pregnant women 1 .

In Brazil, the National Malaria Control Program (PNCM) acknowledged 540,047 cases in 2006, of which more than $99 \%$ were from the Amazon region. Spatial distribution is heterogeneous, however. The overwhelming majority of cases happen in the states of Amazonas, Rondônia, Pará and Acre 2 .

The rationale for malaria control in the country is anchored on early diagnosis and adequate treatment. Treatment is specific for the type of malaria and is based on different phases of the parasite cycle 2 . This leads to complex treatment regimens that include multiple drugs in various combinations and which are applicable to a variety of patients - adults, the elderly, pregnant women and children of different ages.

The Brazilian National Medicines Policy (PNM) lists pharmaceutical services as one of its eight directives and four priorities 3 . The main objectives of pharmaceutical services are to supply quality medicines while guaranteeing their rational use. Because activities pertaining to pharmaceutical services are linked to produce measurable management and clinical outcomes, 
the different elements of pharmaceutical services (such as the organization of services, prescribing and dispensing) are deemed to have important consequences for the adherence to treatment, both by health professionals, who prescribe and dispense, as well as by patients. Therapeutic success will, in turn, influence disease prevalence in endemic areas and drug resistance.

This paper aims to propose a pharmaceutical services evaluation model for endemic diseases in the Brazilian Amazon. To our knowledge the literature has not produced an evaluation model for pharmaceutical services specifically related to endemic diseases. The development of a model based on malaria may be useful to other endemic diseases that share the same control rationale and corroborates the standards stated in the PNM.

\section{Methods}

A search of two literature databases, SciELO and PubMed, for the period January 1980 to December 2005 was conducted to investigate published information on prescribing, dispensing and adherence to malaria treatment.

Other studies on malaria treatment interventions, and further documentation of international organizations such as Management Sciences for Health (MSH), the World Health Organization (WHO), the Pan American Health Organization (PAHO) and the Amazon Antimalarials Surveillance Network (RAVREDA) were also collected.

A specialist panel, composed of researchers in pharmaceutical services and malaria, drafted the theoretical outline. A logical model was prepared, considering the following evaluation components: context, services organization and logistics, prescribing, dispensing and adherence to treatment. They were then organized according to their specific resources, activities, products and expected results.

Based on this framework, indicators for each component were identified. The issue was to consider mainly published validated indicators, in order to increase external validity. In some cases a measure of adaptation was deemed necessary. The choice of indicators was also influenced by the availability of data from the Brazilian Census Bureau (IBGE), the Brazilian Health Information System (DATASUS), the Brazilian Primary Healthcare Database (SIAB) and the Brazilian Epidemiologic Surveillance Database (SIVEP). Indicators were directed towards investigation of municipalities and health facilities within municipalities.

\section{Results and discussion}

The results of this proposal are the logical model and the indicator framework.

The logical model is shown in Table 1. It is organized to characterize inter-component relationships and the influence components have on pharmaceutical services outcomes.

It proposes four components, listing necessary resources for activities to be carried out, expected products for the activities and the evaluation outcomes. Adherence to treatment was understood to be a comprehensive result of all components. Components are referred to in studies on adherence where, in addition to the organization of services and context, prescribing and dispensing are considered as determinants for this outcome 4 .

Adequate organization of services offers a necessary structure for the clinical phases of pharmaceutical services, in health facilities and systems 5 , because drug supply and drug quality are key elements in treatment-based control models, where expected effectiveness is mandatory for success ${ }^{6}$. Since malaria regimens combine various medicines, all must be equally available for first-line and alternative treatments.

The prescription is an important document, used by prescribers, dispensers and other health workers for guidance on treatment 4 . The lack of prescriptions or written instructions is viewed, by those who consider adherence to represent the patient's informed consciousness, to be a true impeditive for its occurrence ?

Dispensing must also present specific characteristics such as prescription checking, counseling on drug administration and use, home storage conditions, adverse effects, preventive measures and follow-up. Dispensing promotes adherence and is, in the lack of household care strategies, the last opportunity of interaction between the health system and the out-patient.

Risk-minimization during therapy is associated with quality prescribing and dispensing. In the case of malaria, misunderstanding the complexity of treatment, as well as the onset of severe adverse effects and resistance, causing and stemming from treatment abandonment, may be interpreted as consequences of faulty counseling 4 .

Adherence is the result of a process involving successive institutional and individual responsibilities. Acceptance of therapeutic guidelines by health professionals is considered to be a necessary pre-condition for patient involvement in treatment. Household follow-up is a powerful incentive to adherence outcomes 4 . In the Brazilian Amazon a theoretical $98 \%$ of municipalities are 
Logical model for evaluation of pharmaceutical services for uncomplicated malaria in the Brazilian Amazon.

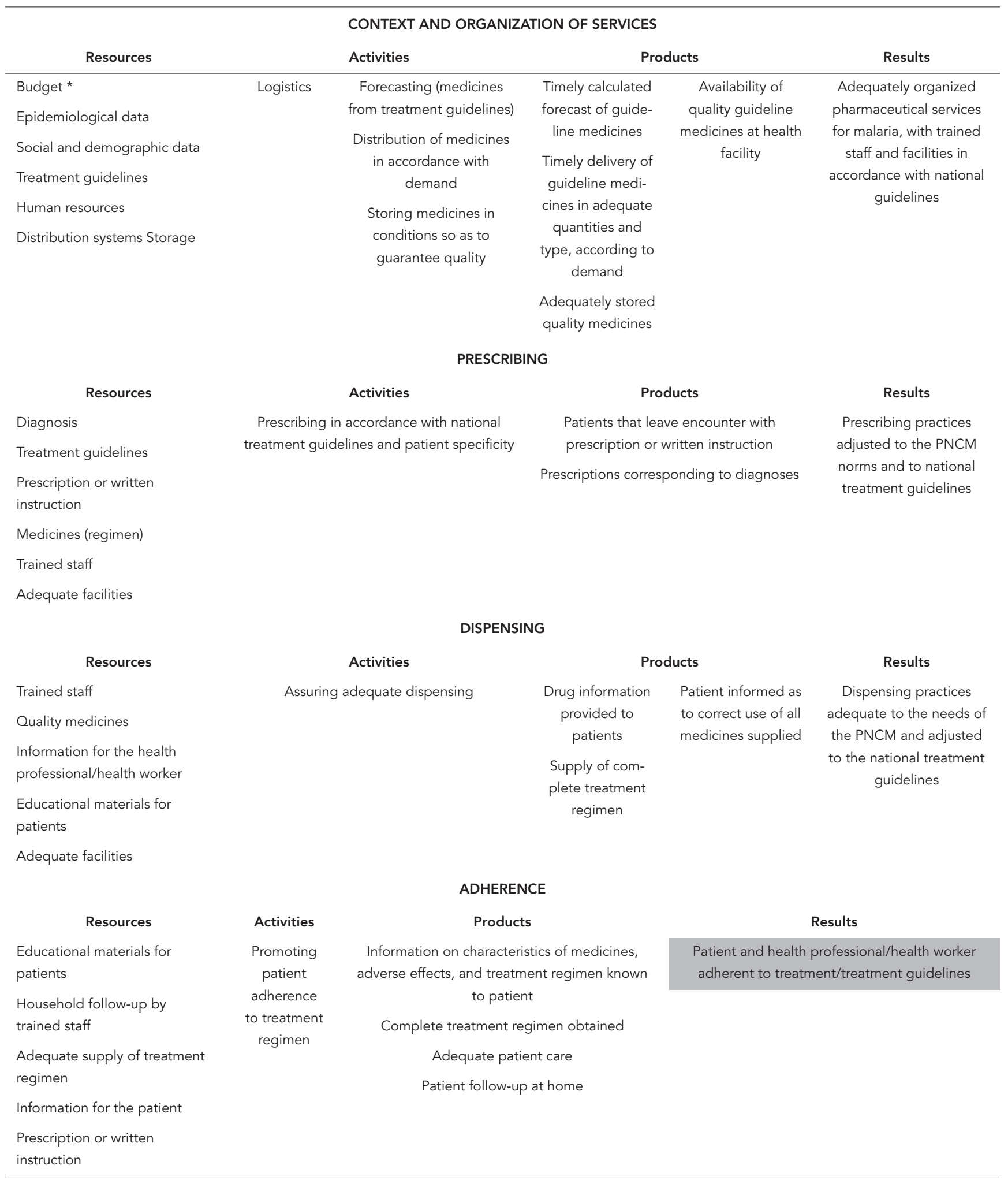

PNCM: National Malaria Control Program.

* In Brazil, malaria treatment is free, $100 \%$ financed by the Ministry of Health.

Comprehensive result. 
served by the Community Health Workers Program (PACS) or Family Health Program (PSF) 8.

Relationships between prescribing, dispensing and adherence in the context of malaria need to be studied not only because cure depends on drug therapy, but also because presumptions and practices may be misconstrued, indicating the need for intervention strategies to correct outcomes 9 .

The logical model gave rise to the indicator framework. Each component and sub-component was translated into one or more indicators, in order to consolidate the evaluation proposal. One guiding option was the listing of the smallest possible number of indicators. This course of action was taken in order to balance the model's theoretical consistency on one hand and the feasibility of the evaluation process on the other.

Twenty-five indicators were considered (Table 2). Sources included information databases, MSH, the PNCM and the literature 2,4,5,10,11,12,13, and some had to be adapted to reflect the context and focus of the evaluation process, namely pharmaceutical services for malaria.

There is no specific way to conduct an evaluation of health services. Each proposal is somewhat dependent on the object under assessment and on the standpoint of the evaluating team 14 . This proposal intends to cluster elements of a normative assessment and of evaluation research, confronting the model with the reality of care in a "natural environment" in order to determine what is acceptable within existing parameters of care. Because investigative methods and instruments must reflect the true nature of the subject under investigation, evaluation research is useful in determining not only priorities for assessment but the best possible strategies for implementing them ${ }^{9}$.

It is not possible to abandon the theoretical basis of pharmaceutical services, even if certain criteria may apparently not be applicable to the context of malaria. An example of this issue is the prescription form. Because prescribing for malaria is not usually carried out by physicians, the evaluation proposal was obliged to incorporate context, allowing for the existence of written instructions as an acceptable alternative. This counterbalance between theory and reality eases the evaluation process, albeit limiting its scope.

The therapeutic use of antimalarials may lead to non-adherence, enhancing resistance and disease prevalence. The challenge of pharmaceutical services is to provide services and medicines in order to counter avoidable health problems and help resolve established ones. The development of an evaluation model of pharmaceutical services for malaria can also contribute to the understanding of this key control strategy for other endemic diseases in Brazil.

\section{Resumo}

A malária é um grave problema de saúde pública em cerca de 90 países. No Brasil, a Amazônia congrega o maior número de casos. No país, o racional de enfrentamento se baseia em diagnóstico precoce e tratamento. A assistência farmacêutica de qualidade é considerada elemento-chave para o controle da doença. Apresenta-se uma proposta de avaliação da assistência farmacêutica, composta por um modelo lógico e uma grade de indicadores, discutidos de modo a estabelecer uma base de comparação e julgamento da forma na qual os serviços são ofertados. O objetivo é contribuir para o entendimento da assistência farmacêutica na malária e em outras endemias, atendendo às diretrizes da Política Nacional de Medicamentos.

Assistência Farmacêutica; Malária; Política Nacional de Medicamentos

\section{Contributors}

C. G. S. Osorio-de-Castro coordinated proposal, development and results, draft and review. G. C. Chaves collaborated on the proposal, development and results, and review. A. M. Ruiz collaborated on the proposal, development and results. E. S. Miranda collaborated on the proposal, development and results, draft and review. M. R. Campos collaborated on the proposal, development, results, and draft. M. C. Suárez-Mútis collaborated on the proposal, development and results, and review. L. F. Freitas collaborated on the proposal, collaborated in development and results.

\section{Acknowledgments}

The authors wish to thank Juliana de Castro Brasil, B.S. Pharmacy, and Paula Pimenta de Souza, Pharmacy student, for their help. This work received financial support from the Brazilian Council for Scientific and Technological Development (CNPq). 
Indicator framework for evaluation of pharmaceutical services for uncomplicated Malaria in the Brazilian Amazon.

CONTEXT AND ORGANIZATION OF SERVICES (CO)

\begin{tabular}{|c|c|c|c|}
\hline Component & Indicator & Detail & Reference \\
\hline CO1 & $\%$ of literate individuals in municipality & $\begin{array}{c}\text { Data from DATASUS, IBGE, SIAB } \\
\text { and RAVREDA }\end{array}$ & Santos \& Natal 5 \\
\hline $\mathrm{CO} 2$ & $\begin{array}{l}\% \text { of households served by water } \\
\text { supply from municipal network }\end{array}$ & $\begin{array}{c}\text { Data from DATASUS, IBGE, SIAB } \\
\text { and RAVREDA }\end{array}$ & Santos \& Natal 5 \\
\hline $\mathrm{CO} 3$ & $\begin{array}{l}\% \text { of households served by municipal } \\
\text { garbage collection }\end{array}$ & $\begin{array}{c}\text { Data from DATASUS, IBGE, SIAB } \\
\text { and RAVREDA }\end{array}$ & Santos \& Natal 5 \\
\hline $\mathrm{CO} 4$ & Municipal coverage by PACS or PSF & $\begin{array}{c}\text { Data from DATASUS, IBGE, SIAB } \\
\text { and RAVREDA }\end{array}$ & Adapted from Santos \& Natal 5 \\
\hline $\mathrm{CO} 5$ & $\begin{array}{l}\text { Number of cases of uncomplicated } \\
\text { malaria (estimated and confirmed) in } \\
\text { the municipality }\end{array}$ & Data from municipal health secretariats & Adapted from Santos \& Natal 5 \\
\hline $\mathrm{CO} 6$ & $\begin{array}{l}\% \text { of resistance to first-line treatment } \\
\text { regimen of most prevalent form of } \\
\text { malaria in the municipality }\end{array}$ & Data from the PNCM & $\begin{array}{l}\text { Adapted from World Health } \\
\text { Organization } 10\end{array}$ \\
\hline $\mathrm{CO}$ & $\begin{array}{l}\text { Number of antimalarials on the } \\
\text { national guidelines that progressed to } \\
\text { Phase III clinical trials in Brazil }\end{array}$ & $\begin{array}{l}\text { Assesses adequacy of national treatment guidelines } \\
\text { to published evidence }\end{array}$ & Freitas et al. 11 \\
\hline $\mathrm{CO} 8$ & $\begin{array}{l}\text { Availability of the MTM or of official } \\
\text { prescriber guidance material for } \\
\text { malaria from the Ministry of Health at } \\
\text { the health facility }\end{array}$ & $\begin{array}{c}\text { The MTM is published by the Ministry of Health and } \\
\text { includes the official treatment guidelines. At least } \\
\text { one perfectly readable copy of the } 2001 \text { version } \\
\text { should be present in the facility. Other official } \\
\text { guidance material from the Ministry of Health is } \\
\text { alternatively accepted }\end{array}$ & $\begin{array}{l}\text { Adapted from Fundação Nacional } \\
\text { de Saúde/Ministério da Saúde 2, and } \\
\text { World Health Organization } 12\end{array}$ \\
\hline CO9 & $\begin{array}{c}\text { Number of available complete } \\
\text { treatment regimens for uncomplicated } \\
\text { malaria caused by Plasmodium vivax } \\
\text { and/or } P \text {. falciparum at the health } \\
\text { facility }\end{array}$ & $\begin{array}{l}\text { In order to fill out this indicator, prevalence data from } \\
\text { the municipality, number of cases per month at the } \\
\text { health facility and stock of medicines are needed }\end{array}$ & $\begin{array}{l}\text { Adapted from World Health } \\
\text { Organization } 12\end{array}$ \\
\hline CO10 & Good Storage Practices & $\begin{array}{l}\text { A checklist for storage conditions and practices } \\
\text { is suggested, composed of mandatory structural } \\
\text { elements, hygiene conditions, storage practices, } \\
\text { organization and stock control }\end{array}$ & $\begin{array}{l}\text { Adapted from Management Sciences } \\
\text { for Health } 13\end{array}$ \\
\hline CO11 & $\begin{array}{l}\text { Existence of expired antimalarials at } \\
\text { the health facility }\end{array}$ & $\begin{array}{c}\text { Stock for antimalarials composing regimens for the } \\
\text { most prevalent type of malaria in the municipality } \\
\text { should be investigated as to expiry date in each } \\
\text { health facility }\end{array}$ & $\begin{array}{l}\text { Adapted from World Health } \\
\text { Organization } 10 \text { and Santos \& Natal } 5\end{array}$ \\
\hline $\mathrm{CO} 12$ & $\begin{array}{l}\text { Uninterrupted supply of first-line } \\
\text { antimalarials at the health facility }\end{array}$ & $\begin{array}{l}\text { The health facility must follow some procedure of } \\
\text { stock control. Uninterrupted supply for regimens for } \\
\text { the most prevalent type of malaria in the municipality } \\
\text { should be checked, from forecasting forms and } \\
\text { supply dates }\end{array}$ & $\begin{array}{l}\text { Adapted from World Health } \\
\text { Organization } 12\end{array}$ \\
\hline $\mathrm{CO} 13$ & $\begin{array}{l}\% \text { of encounters in which diagnosis } \\
\text { occurs before prescription of } \\
\text { treatment regimen }\end{array}$ & $\begin{array}{l}\text { An encounter is characterized by a patient meeting } \\
\text { a health professional/health worker for diagnosis/ } \\
\text { treatment/counseling, at the health facility or at } \\
\text { home. Diagnosis involves the determination of the } \\
\text { type of malaria from a blood sample, according to } \\
\text { the PNCM. The date of diagnosis and the date of } \\
\text { treatment assignation will be investigated }\end{array}$ & $\begin{array}{l}\text { Adapted from Fundação Nacional } \\
\text { de Saúde/Ministério da Saúde } 2 \text { and } \\
\text { World Health Organization } 10\end{array}$ \\
\hline
\end{tabular}

(continues) 
Table 2 (continued)

CONTEXT AND ORGANIZATION OF SERVICES (CO)

\begin{tabular}{lc} 
Component & Indicator \\
\hline C014 & $\begin{array}{c}\text { Average period from blood sample to } \\
\text { diagnosis }\end{array}$
\end{tabular}

CO15

P1

P2

P3

\section{Component}

D1

D2
$\%$ of trained health professionals/ trained health workers (in diagnosis and treatment) attending to malaria patients

Existence of specific facilities for patient encounter (for prescribing and dispensing)

\section{Indicator}

$\%$ of patients with uncomplicated malaria that report at dispensing with a prescription or written instructions

Average number of medicines in the prescription or in written instructions originating from the same encounter, apart from the ones from MTM

$\%$ of encounters for uncomplicated malaria treatment in which prescribing (or indication) is done in accordance with MTM

\section{Indicator}

$\%$ of dispensing encounters in which patients/caregivers receive information on the treatment regimen

$\%$ of medicines adequately labeled for patient delivery

\section{Detail}

Reference

Diagnosis involves determination of type of malaria for adequate treatment assignation. The date of blood sampling and the date of result/diagnosis will be investigated

Training involves receiving the patient, collecting patient history, blood sampling and lab work, interpretation of results, diagnosis, indication of treatment and adequate dispensing (including counseling)

Locale where patient is received and where encounters (including prescribing and dispensing) take place

\section{PRESCRIBING (P)}

\section{Detail}

Patients, having searched for diagnosis and treatment, may have been provided with a prescription or written instructions on their treatment regimens. Written instructions may also be in the form of pre-printed flyers, pamphlets etc and are given out by health professionals / health workers The investigation is to be done when the patient exits the dispensing area

In theory, any patient might receive a prescription for different ailments at the same encounter when he or she is being treated for malaria. The patient will be asked for his or her prescription or written instruction received in order to assess whether other medicines, (apart from antimalarials), were prescribed and how many. A group of patients will characterize a health facility and the group of facilities will characterize a municipality

Certain criteria must be followed: if the prescription/ written instruction is done in accordance with the diagnosis; if the treatment regimen is part of the official guidelines; if prescribed by generic name; if the complete treatment regimen is prescribed

\section{DISPENSING (D)}

\section{Detail}

Dispensing is observed for assessment of: existence of prescription or written instructions; delivery of complete treatment regimen; information relayed to patient (at least: dosing information, household storage, common adverse effects); available literature for health professionals/workers

Dispensing is observed to assess labeling of delivered medicines. Minimally accepted are name of medicines on labels to coincide with the one on the prescription/instruction and dosing
Adapted from Fundação Nacional de Saúde/Ministério da Saúde 2 and World Health Organization 10

Adapted from Santos \& Natal 5

Adapted from Santos \& Natal 5 and Osterberg \& Blaschke ${ }^{4}$

\section{Reference}

Adapted from Osterberg \& Blaschke 4

Adapted from Fundação Nacional de Saúde/Ministério da Saúde 2, World Health Organization 12 and Osterberg \& Blaschke 4

Adapted from Fundação Nacional de Saúde/Ministério da Saúde 2, World Health Organization 12 and Freitas et al. 11

Reference

Adapted from Osterberg \& Blaschke ${ }^{4}$

World Health Organization 12 
PRESCRIBING/DISPENSING (PD)

\begin{tabular}{lc} 
Component & Indicator \\
\hline PD1 & \% of patients/caregivers that exit the \\
& health facility adequately informed as \\
& to the treatment regimen
\end{tabular}

Detail

Reference

Acceptable minimal information depends on: receipt of complete treatment regimen; capacity to relay to interviewer how to take the medicines; household storage and common adverse effects. If information given by patient has been sub-optimal, interviewer is to complement it

\section{ADHERENCE (A)}

Component

Indicator

A1

$\%$ of patients receiving care for malaria at home from community/family health program workers

A2

$\%$ of patients that declare having completed their treatment in accordance with prescription/written instruction

A3

$\%$ of patients that at household visit present difference between expected number of pills/capsules (dosage forms) and those actually presented to interviewer

\section{Detail}

Household visit by health workers is investigated in the municipality in order to assess if worker is adequately trained for diagnosis and treatment, if worker relays relevant information to the patient on antimalarials and adverse effects, if physical assessment of patients is done, if blood sampling and counseling are carried out, if educational materials are made available

A statistically established fraction of patients interviewed exiting the dispensing area that present a prescription or written instruction, that received a complete treatment regimen, and that live in an accessible location ( $<1$ hour from the health facility) are followed at household after 2 or 5 days of treatment (depends on regimen). Adherence is assessed through the self-reported method (report of daily treatment progress and experienced problems, including adverse effects). In case of sub-optimal adherence, the patient will be referred back to the health facility

A statistically established fraction of patients interviewed exiting the dispensing area that present a prescription or written instruction, that received a complete treatment regimen, and that live in an accessible location ( $<1$ hour from the health facility) are followed at household after 2 or 5 days of treatment (depends on regimen). The researcher will demand to see the medicines received at encounter to treat malaria. Dosage forms will be counted for comparison with expected number. In case of suboptimal adherence, the patient will be referred back to the health facility
Adapted from World Health Organization 12

Reference

Adapted from Santos \& Natal 5

Adapted from Osterberg \& Blaschke 4

Adapted from Osterberg \& Blaschke 4

DATASUS: Brazilian Health Information System; IBGE: Brazilian Census Bureau; SIAB: Brazilian Primary Healthcare Database; RAVREDA: Amazon Antimalarials Surveillance Network; PACS: Community Health Worker Program; PSF: Family Health Program; PNCM: National Malaria Control Program; MTM: National Malaria Treatment Guideline. 


\section{References}

1. Snow RW, Guerra CA, Noor AM, Myint HY, Hay SI. The global distribution of clinical episodes of Plasmodium falciparum malaria. Nature 2005; 434:214-7.

2. Fundação Nacional de Saúde/Ministério da Saúde. Manual de terapêutica da malária. Brasília: Fundação Nacional de Saúde/Ministério da Saúde; 2001.

3. Brasil. Portaria no. 3.916/MS/GM. Aprova a Política Nacional de Medicamentos. Diário Oficial da União 1998; 30 out.

4. Osterberg LMD, Blaschke TMD. Drug therapy: adherence to medication. N Engl J Med 2005; 353:487-97.

5. Santos EM, Natal S, organizadores. Dimensão técnico-operacional. Unidade didático-pedagógica: modelo teórico de avaliação. Rio de Janeiro: ABRASCO; 2006. (Série Ensinando Avaliação, 2).

6. Luiza VL, Osorio-de-Castro CGS, Nunes JM. Aquisição de medicamentos no setor público: o binômio qualidade-custo. Cad Saúde Pública 1999; 15:769-76.

7. Farmer P. Social scientists and the new tuberculosis. Soc Sci Med 1997; 44:347-58.

8. Departamento de informática do SUS. Sistema de Informação de Atenção Básica - cadastramento familiar - Brasil. http://tabnet.datasus.gov.br/cgi/ deftohtm.exe?siab/cnv/SIABFbr.def (accessed on 05/Aug/2005)
9. Uchimura KY, Bosi MLM. Qualidade e subjetividade na avaliação de programas e serviços em saúde. Cad Saúde Pública 2002; 18:1561-9.

10. World Health Organization. Monitoring and evaluation toolkit: HIV/AIDS, tuberculosis and malaria. Geneva: World Health Organization/The Global Fund/The United Nations Joint Programme on HIV/AIDS/United States Agency for International Development/Centers for Disease Control and Prevention/United Nations Children's Fund/World Bank; 2006.

11. Freitas LF, Chaves GC, Wannmacher L, Osorio-deCastro CGS. Malária não-complicada por Plasmodium vivax e $P$ falciparum no Brasil: evidências sobre fármacos isolados e associações medicamentosas empregados em esquemas terapêuticos recomendados pelo protocolo terapêutico oficial. Cad Saúde Pública 2007; 23:2285-94.

12. World Health Organization. How to investigate drug use in health facilities: select drug use indicators. Geneva: World Health Organization; 1993.

13. Rational Pharmaceutical Management Project, Management Sciences for Health. Rapid pharmaceutical management assessment: an indicatorbased approach. Arlington: Management Sciences for Health; 1995.

14. Silver L. Aspectos metodológicos em avaliação dos serviços de saúde. In: Gallo E, organizador. Planejamento criativo: novos desafios em políticas de saúde. Rio de Janeiro: Editora Relume-Dumará; 1992. p. 195-209.

Submitted on 15/Aug/2008

Final version resubmitted on 12/Feb/2009

Approved on 19/May/2009 